\title{
Blocking Possibilities
}

\author{
Jyotirmoy Sarkar ${ }^{1}$
}

\section{ABSTRACT:}

Education is a very essential part of our life. To know ourselves better, to know the society better, we have to be educated, without education progress is not possible. Every person has the right to be educated. Every person has the right to attend school, college and university.

We should have some minimum qualification so that we don't face any problem in bank, post office and such official works and also we can better understand the society, the economy, the politics etc, but above all the practical application of our knowledge is very much necessary, the more higher our qualification is the more responsibility we have to make the proper application of our knowledge.

Now a day's few people are doing higher degrees either to get a good reputation in society or to be qualified as a good bride or groom, neither they are trying for job nor they are applying their knowledge in any field, actually they are blocking a seat in College and University in this tough competition era and so blocking the possibility of making proper application of that opportunity they have got.

Keywords: Academic Achievement, Self-assessment, Social awareness, Consciousness.

\section{Different Types of Needs:}

We have to earn and for that we have to be self-dependent because it's necessary part of our life and to do that we need a minimum qualification. Generally the minimum qualification for job is graduation. Those who want to be self dependent those who want to do job can be classified in two categories----one, those whose financial condition is not good at all so by doing a job and earning money they want to support their family financially, and second types are those whose financial condition is good but they want to be independent.

Those whose financial conditions are not good, generally they try for job after completing graduation and if they get any job before graduation they join the job so that they can support their family financially. There are few persons among these, those who have interest in study that's why it can be found later that those study interested persons carry on their study after gaining a stable financial condition. Those whose financial condition is good, they start searching jobs after graduation and parallel they continue their master degree course. If such people get job in graduation degree then they complete their master degrees either in own interest or for promotion in job.

${ }^{1}$ Science Graduate

(C) 2015 I J Sarkar; licensee IJIP. This is an Open Access Research distributed under the terms of the Creative Commons Attribution License (http://creativecommons.org/licenses/by/2.0), which permits unrestricted use, distribution, and reproduction in any Medium, provided the original work is properly cited. 


\section{Blocking Possibilities}

The upper mentioned processes are very general processes but very much necessary for our life and it's natural. Generally most of the people do so.

Those who have hunger for knowledge, those who have huge interest to enrich their knowledge generally carry on their study after getting jobs, sometime due to pressure in work field or to perform their duties and responsibilities they can't continue their higher studies but they carry on their studies by their own urge. There are few persons who have interest in research so they go for it after achieving the degree.

\section{The Problem:}

But there is another type of people who-does hard work to secure very good marks in class $\mathrm{X}$ standard exam then they take admission in a famous schools and again do hard work to secure very good marks in class XII standard exam ,they secure good marks then they take admission in a good college and after that in university and in master degree they secure good marks doing hard work and ------after completing graduation/master degree with good marks this type of girls

are seen to be get married with a person with good qualification and salary, these type of girls neither can be seen to take preparation for job nor can after marriage they are trying for jobs, and after one or two years of marriage they can be seen with their own child in their lap-------this is a fact and it can be seen around us.

Now the question is - is there any necessity of graduation or master degree to become a mother of a child or to bring up a child. If we analyze it with logic then we will understand that there is no necessity of it.

The primary and important teachings a child should get from his /her mother are moral values, ethics, manners etc, is graduation or master degree necessary to teach these things? As per our present education system, there is no subject, no teaching, no process to evaluate our moral values, ethics manners etc. There is no process in our educational system to analyze our morals, ethics, manners etc and to give a final mark sheet on character upon those evaluations.

So logically it means that if after achieving a higher degree we don't use it for a good purpose, if we don't make practical application of it, those degrees are being locked in the locker of almirah----then what is the necessity to achieve such higher degrees?

\section{Wrong Message:}

Now let's see what can be the negative side of such works....now a day's competition is very tough, we also know that the seat limits in college and university is very limited, Now after securing good marks a student takes admission in a good college then again securing good marks that student takes admission in a good university and then after collecting the mark sheets and certificates that student keeps those certificate and mark sheet in the safety locker of almery because she is married now. To collect those mark sheets and certificates she has been blocking a seat for long time and ultimately she makes no practical application of her long time hard work. It could happen that the seat she has been blocking for long could have been given to another student just one or two marks less than her and that student could make his/her carrier in the study field or by doing practical application of his/her knowledge in any field. May be being a self dependent person or in research field or teaching others or in business field etc. Those who are blocking a seat till university level; and then making no practical application of their knowledge, those who are reading only to earn degrees---actually destroying a good possibility, nothing more than it. Most importantly, the message they are giving to the society can't be called a positive message. What can we learn from them?------make good result in classes then celebrate it with friends and relatives and family then make good result in class X, Class XII 


\section{Blocking Possibilities}

,graduation and in university and again and again celebrate with close ones and if you do this then a notion in the mind of the people will grow that one day you will do something good or it can be said in another way that after securing good marks celebrating with close ones is actually a means to spread the message that how much good student you are .to secure a good position in the society, intentionally create a sense in the mind of neighbors and relative that how much meritorious student you are, -----and one day suddenly get married if you get a boy with good salary and good job and there is no need to fight or to try for job or to do something independently before or after marriage .......this is the teaching they are giving to the society. Sometime these types of girls get married because their friend is getting married and these types of thoughts come into mind due to the lack of self--assessment and a huge interest in show off, yes it's true that some time due to some emotional pressure they have to get married but as I have mentioned earlier that after marriage they are not seen to apply their knowledge, they are not seen to make proper use of their mark sheets they have collected after a long fight. The most interesting fact is these types of girls can't be called as less meritorious students rather some of them are really meritorious and some have average merit, that's why it is matter to feel sorry for them as we are losing a good student.

But for all these we can't blame some girls only, some boys have fault also. Now a day's brides with master degrees are much in demand, otherwise second chance have those brides who has graduation degrees....because it's all about show off in society, having a wife with higher qualification increases the status in the society and its less matters to them how her character is, this is the thought of some people and for all this demands some girls are studying only to earn a degree, especially those who are like minded with those boys, actually they don't have any planning to apply their knowledge in any field. Marriage is a mental and spiritual connection between two people and also between two families, now will this mental and spiritual connection is stronger if the girl is a master degree holder or a graduate? Actually nobody can give a good logic that what is the relation between marriage and higher degrees? I am talking about marriage, not about a mutual understanding between two people.

\section{CONCLUSION:}

These types of behavior are actually comes from lack of consciousness, lack of self-assessment and specially from a weak mentality, everyone wants to secure their life and when it is become secured then less number of people have the mentality to work for the society to try to make something good to the society and to the people. Self-assessment, self-analysis, good ethics and moral values etc should teach in school and colleges and every student should know how to apply their knowledge for the well fare of the society and for the people, social consciousness is very much necessary in this tough competition era. We can't blame anybody particularly, actually we all have some faults - the wrong message will be spread in society and one day it will be the rule of the society until we all try to make ourselves correct .

\section{REFERENCES:}

1. Harry D. Kitson. How to use your mind. Available from: http://manybooks.net/_scripts/send.php?tid=kitsonh10671067410674-8\&book=1:pdf:.pdf:pdf

2. Charles Stangor, Introduction to Psychology.

Flat World Knowledge 2010

3. Edward L. Thorndike, Educational Psychology.

Teachers College, Columbia University, New York, 1910.

4. John Dewey, How We Think.

D.C. Health \& Co., 1910 